\title{
Effect of plant spacing and variety on weed and performance of orange-fleshed sweet potato in humid agro-ecological zone of Nigeria
}

\author{
L.P. Ogbologwung ${ }^{I}$ D.A. Okpara ${ }^{I}$ and J.C. Njoku ${ }^{2}$ \\ ${ }^{1}$ College of Crop and Soil Sciences, Michael Okpara University of Agriculture, Umudike, Abia State, \\ Nigeria \\ ${ }^{2}$ National Root Crops Research Institute Umudike, Abia State, Nigeria
}

Author for correspondence: daokpara@yahoo.com

\begin{abstract}
Among the crops grown in the tropics, sweet potato ranks second after cassava. Field research was conducted at the National Root Crops Research Institute, Umudike, south-eastern Nigeria, to evaluate the response of orange-fleshed sweet potato varieties to intra-row spacing. Treatments included four varieties (Umuspo 1, Umuspo 3, Ex-Igbariam and Ex-Oyunga) and three intra - row spacings $(20,30$ and $40 \mathrm{~cm})$. Weed density and growth decreased, but sweetpotato leaf area index (LAI), fresh shoot biomass and storage root yield increased significantly $(\mathrm{P}<0.05)$ at the closer spacing $(20 \mathrm{~cm})$ than at the wider spacings $(30$ and $40 \mathrm{~cm})$. Umuspo $1 \mathrm{had}$ higher LAI and shoot biomass; and suppressed weeds more than other varieties. Also, storage root yield of Umuspo 1 (27.2t/ha) was significantly higher than that of Umuspo 3, Ex-Igbariam and Ex-Oyunga by 35, 103 and $325 \%$, respectively.
\end{abstract}

Key words: Plant spacing, variety, yield, orange-fleshed, sweet potato, Nigeria

\section{Introduction}

Among the crops grown in the tropics, sweet potato ranks second after cassava (Ray and Ravi, 2005). Within sub-Saharan Africa, its ranks third after cassava and yam (Hahn and Hozyo, 1998). The orange-fleshed sweet potato (OFS) contains more beta carotene than the yellow or white types, and is very important in Africa where the deficiency of vitamin $\mathrm{A}$ is a serious health problem (FAO, 2011). The increasing potential of the crop in poverty alleviation and food security due to its higher productivity per area and time makes it a candidate crop for the survival of resource poor farmers especially in countries like Nigeria (NRCRI, 2005). 
Yield variables of crops are influenced by plant competition or by changes in plant population density. Plant spacin/g or density is, therefore, a major determinant of crop yields. Normally, yield per unit area tends to increase as plant density increases up to a point and then declines (Akintoye et al., 2009). Although a closer spacing is recommended for sweet potato to achieve maximum yields, the determinants of optimum population density include soil fertility, cultivar and environment (Chambi and Taylor, 1986; Nedhnchezhiyan et al., 2012). While the recommended spacing for sweetpotato is $1 \mathrm{~m} x$ 0.3m (Egeonu and Akoroda, 2009). This research examined the effect of intrarow spacing on weeds and on growth and yield of four orange-fleshed sweet potato varieties in south-eastern Nigeria.

\section{Materials and methods}

The experiment was conducted during the 2013 and 2014 cropping seasons at the National Root Crops Institute, Umudike farm south eastern Nigeria. Umudike is situated at latitude $05^{\circ} 29^{\prime} \mathrm{N}$, longitude $07^{\circ}$ 33 ' $\mathrm{E}$ and altitude $122 \mathrm{~m}$. The soil is a sandy loam and had $\mathrm{pH}\left(\mathrm{H}_{2} 0\right)=4.7$, organic matter $=1.59 \%$, total $\mathrm{N}=0.08 \%, \mathrm{P}=$ $32.1 \mathrm{mg} / \mathrm{kg}$ and $\mathrm{K}^{+}=0.35 \mathrm{cmol} / \mathrm{kg}$ ) in 2013. In 2014, the soil had $\mathrm{P}^{\mathrm{H}} 4.5$, organic matter $2.22 \%, \mathrm{~N} 0.09 \%, \mathrm{~N} 0.09 \%, \mathrm{P} 43.6$ $\mathrm{mg} / \mathrm{kg}$ and $0.20 \mathrm{cmol} / \mathrm{kg}$.

Treatments were laid out as split-plot in randomised complete block design with three replications. The main plot treatments were four orange-fleshed sweet potato varieties (Umuspo 1, Umuspo 3, ExOyunga and Ex-Igbariam). Storage root flesh colour is light orange for Umuspo 1, dark orange for Umuspo 3, orange for ExOyunga and yellow for Ex-Igbariam. The sub-plot treatments were the intra-row spacings of 20, 30 and $40 \mathrm{~cm}$ along the crest of ridges, giving a plant population of 50,000, 33,333 and 25,000 plants/ha, respectively. Each sub plot measured $3 \mathrm{~m}$ $\mathrm{x} 2 \mathrm{~m}\left(6 \mathrm{~m}^{2}\right)$ while the main plot measured $9 \mathrm{~m} \mathrm{X} 6 \mathrm{~m}\left(54 \mathrm{~m}^{2}\right)$

The sweet potato vine cuttings were planted on 24 June, 2013 and on 17 May, 2014. Supply of vacant stands was done at 2 weeks after planting (WAP). NPK fertiliser $(15: 15: 15)$ at $400 \mathrm{~kg} / \mathrm{ha}$ was applied 4WAP by band placement. Hoeweeding was done at $8 \mathrm{WAP}$ and weeds were sampled using a $1 \mathrm{~m} \mathrm{x} 1 \mathrm{~m}$ quadrat. The crop measurements were on leaf area index, fresh shoot biomass (t/ha), number of storage roots/plant, storage root weight $(\mathrm{kg})$ and storage root yield (t/ha). Four plants from each sub plot were sampled for leaf area while all plants in the plot were sampled for shoot biomass and yield and yield components. Leaf area used for leaf area index determination was estimated by the disc method according to Kelm et al (2001) method. Leaf area index was calculated as $\mathrm{L}=\mathrm{LA} / \mathrm{P}$, where $\mathrm{L}=$ leaf area index, $\mathrm{LA}=$ total leaf area per plant, $\mathrm{P}=$ land area occupied by the plant. The number of storage roots was counted while shoot biomass and storage roots were weighed. Shoot biomass and storage root yield were expressed in tons per hectare. The data were subjected to analysis of variance using GenStat (2007) statistical package.

\section{Results}

The total weed density increased significantly with increase in intra-row spacing up to $40 \mathrm{~cm}$ (Table 1). Among the varieties, Ex-Oyunga had the highest number of weeds, followed by Umuspo 3 and Ex-Igbariam; while Umuspo 1 had the lowest weed density in 2014. In both years, 
Table 1. Effect of plant spacing and variety on weed density $\left(\mathrm{no}^{\left.-\mathrm{m}^{2}\right)}\right.$ at 8 WAP in 2013 and 2014

\begin{tabular}{|c|c|c|c|c|}
\hline \multirow[t]{3}{*}{ Variety } & \multicolumn{3}{|c|}{ Plant spacing $(\mathrm{cm})$} & \multirow[b]{3}{*}{ Mean } \\
\hline & \multirow[b]{2}{*}{20} & \multicolumn{2}{|l|}{2013} & \\
\hline & & 30 & 40 & \\
\hline Umuspo 3 & 18.50 & 29.50 & 32.83 & 26.94 \\
\hline Umuspo 1 & 23.83 & 18.67 & 35.83 & 26.11 \\
\hline Ex-Oyunga & 17.67 & 26.50 & 36.50 & 26.89 \\
\hline Ex-Igbariam & 18.33 & 18.80 & 37.67 & 24.93 \\
\hline \multirow[t]{2}{*}{ Mean } & 19.58 & 23.37 & 27.21 & 26.22 \\
\hline & \multicolumn{3}{|c|}{2014} & \\
\hline Umuspo 3 & 25.50 & 45.80 & 73.70 & 48.33 \\
\hline Umuspo 1 & 20.50 & 33.70 & 45.50 & 33.23 \\
\hline Ex-Oyunga & 36.20 & 62.00 & 90.20 & 62.80 \\
\hline Ex-Igbariam & 27.50 & 44.50 & 70.20 & 47.40 \\
\hline \multirow[t]{2}{*}{ Mean } & \multirow[t]{2}{*}{27.43} & \multirow[t]{2}{*}{46.50} & 69.90 & 47.94 \\
\hline & & & 2013 & 2014 \\
\hline LSD (0.05) for spacing $(\mathrm{S})$ Mean & & $=$ & 3.02 & 3.5 \\
\hline $\operatorname{LSD}(0.05)$ for variety $(\mathrm{V})$ Mean & & $=$ & NS & 9.0 \\
\hline $\operatorname{LSD}(0.05)$ for $S x \mathrm{~V}$ Mean & & $=$ & NS & NS \\
\hline
\end{tabular}

$\mathrm{NS}=$ Not significant at $\mathrm{P}<0.05$

there was no plant spacing by variety interaction $(\mathrm{P}>0.05)$ for weed density.

Similarly, weed dry matter progressively increased significantly with wider spacings in 2014 (Table 2). Weed biomass at the closer spacing $(20 \mathrm{~cm})$ was lower than the values $(30$ and $40 \mathrm{~cm}$ ) intrarow spacing by 57 and $68 \%$, respectively. Umuspo 1 and Umuspo 3 varieties had significantly lower weed dry matter than Ex-Igbariam, which also had lower weed biomass than Ex-Oyunga. Interactions of planting spacing and variety did not produce significant effects $(\mathrm{P}>0.05)$ on weed dry weight.
In both years, LAI was significantly higher at the narrow spacing of $20 \mathrm{~cm}$ than at the wider spacings (Table 3). Also, orange fleshed sweetpotato Umuspo 1 consistently had higher LAI than other varieties. Interactions were significant in 2014 , with highest LAI of 8.4 produced in Umuspo 1 at the closer spacing $(20 \mathrm{~cm})$.

Fresh shoot biomass of the orange fleshed sweetpotato was not affected by spacing in 2013, but in 2014, the narrow intra-row spacing of $20 \mathrm{~cm}$ had significantly higher fresh top yield than the wider spacings (Table 4). Shoot yield of $20 \mathrm{~cm}$ spacing in 2014 was 46 and $87 \%$ 
Table 2. Effect of plant spacing and variety on weed dry matter $\left(\mathrm{g} / \mathrm{m}^{2}\right)$ at 8 WAP in 2014

\begin{tabular}{|c|c|c|c|c|}
\hline \multirow[t]{3}{*}{ Variety } & \multicolumn{3}{|c|}{ Plant spacing $(\mathrm{cm})$} & \multirow[b]{3}{*}{ Mean } \\
\hline & \multirow[b]{2}{*}{20} & \multicolumn{2}{|l|}{2013} & \\
\hline & & 30 & 40 & \\
\hline Umuspo 3 & 24.5 & 64.0 & 38.6 & 42.4 \\
\hline Umuspo 1 & 28.0 & 22.8 & 30.8 & 27.2 \\
\hline Ex-Oyunga & 40.2 & 22.8 & 28.9 & 30.6 \\
\hline Ex-Igbariam & 17.8 & 21.6 & 30.1 & 23.2 \\
\hline \multirow[t]{2}{*}{ Mean } & 27.6 & 32.8 & 32.1 & \\
\hline & & \multicolumn{2}{|l|}{2014} & \\
\hline Umuspo 3 & 6.30 & 9.40 & 24.50 & 13.4 \\
\hline Umuspo 1 & 4.00 & 15.80 & 18.00 & 12.6 \\
\hline Ex-Oyunga & 15.00 & 29.70 & 41.80 & 28.8 \\
\hline Ex-Igbariam & 9.00 & 25.20 & 21.60 & 18.6 \\
\hline \multirow[t]{2}{*}{ Mean } & 8.58 & 20.03 & 26.48 & \\
\hline & & 2013 & 2014 & \\
\hline $\operatorname{LSD}_{(0.05)}$ for spacing (S) Mean & & $=$ & 3.00 & \\
\hline $\mathrm{LSD}_{(0.05)}$ for variety $(\mathrm{V})$ Mean & & $=$ & 5.40 & \\
\hline $\operatorname{LSD}_{(0.05)}$ for S x V Mean & & $=$ & NS & \\
\hline
\end{tabular}

NS $=$ Not significant at $\mathrm{P}<0.05$

higher than those of the wider spacings of 30 and $40 \mathrm{~cm}$, respectively. Variety Umuspo 1 produced shoot yield that was on average higher by 233,228 and $53 \%$ than those of Umuspo 3, Ex-Oyunga and Ex-Igbariam, respectively. Spacing X variety interactions were not significant $(\mathrm{P}>0.05)$ on above ground biomass accumulation..

The number of storage roots was not affected by spacing in both the years (Table 5). The varieties, however, varied significantly in number of storage roots per plant. Overall, Umuspo 1 variety gave the highest number of storage roots; while ExOyunga had the least.

Unlike number of storage roots per plant, storage root yield of the orange fleshed sweetpotato increased significantly at the closer spacing $(20 \mathrm{~cm})$ than at the wider spacings ( 30 and $40 \mathrm{~cm}$ ) by 52 and $108 \%$, respectively, (Table 6 ). Across the two cropping seasons, root yield was $23.5 \mathrm{t} / \mathrm{ha}$ at the intra-row spacing of $20 \mathrm{~cm}$. Average storage root yield obtained from Umuspo 1 variety was $27.2 \mathrm{t} / \mathrm{ha}$ and this was significantly the highest, followed by Umuspo 3; while Ex- 
Table 3. Effect of plant spacing and variety on leaf area index of orange-fleshed sweetpotato at 12 WAP in 2013 and 2014

\begin{tabular}{|c|c|c|c|c|}
\hline \multirow[t]{3}{*}{ Variety } & \multicolumn{3}{|c|}{ Plant spacing $(\mathrm{cm})$} & \multirow[b]{3}{*}{ Mean } \\
\hline & \multirow[b]{2}{*}{20} & \multicolumn{2}{|l|}{2013} & \\
\hline & & 30 & 40 & \\
\hline Umuspo 3 & 3.03 & 0.52 & 0.46 & 1.34 \\
\hline Umuspo 1 & 7.05 & 4.32 & 3.90 & 5.09 \\
\hline Ex-Oyunga & 4.14 & 2.11 & 1.30 & 2.52 \\
\hline Ex-Igbariam & 4.85 & 2.80 & 1.55 & 3.07 \\
\hline \multirow[t]{2}{*}{ Mean } & 4.77 & 2.44 & 1.80 & 3.01 \\
\hline & & \multicolumn{2}{|l|}{2014} & \\
\hline Umuspo 3 & 1.80 & 0.87 & 0.79 & 1.15 \\
\hline Umuspo 1 & 8.42 & 4.52 & 2.69 & 5.21 \\
\hline Ex-Oyunga & 4.47 & 2.69 & 1.32 & 2.83 \\
\hline Ex-Igbariam & 5.26 & 2.94 & 1.49 & 3.23 \\
\hline \multirow[t]{2}{*}{ Mean } & 4.99 & 2.76 & 1.57 & 3.11 \\
\hline & & 2013 & 204 & \\
\hline LSD $_{(0.05)}$ for spacing (S) Mean & $=$ & 0.77 & (8) & \\
\hline $\mathrm{LSD}_{(0.05)}$ for variety $(\mathrm{V})$ Mean & $=$ & 0.76 & Q万 & \\
\hline $\operatorname{LSD}_{(0.05)}^{(0.0)}$ for S x V Mean & $=$ & NS & 1.27 & \\
\hline
\end{tabular}

NS $=$ Not significant at $\mathrm{P}<0.05$

Oyunga had the lowest yield. Interactions were significant in 2014, with Umuspo 1 at the narrow spacing of $20 \mathrm{~cm}$ producing the highest yield of $56.3 \mathrm{t} / \mathrm{ha}$, followed by Umuspo 3 while Ex-Oyunga had the lowest yields at the wider spacings of 30 and $40 \mathrm{~cm}$.

Top and storage root yields were negatively and significantly correlated with inter-row spacing in 2014 (Table 7). Shoot biomass and storage root yields were negatively but not significantly correlated with spacing in 2013.

\section{Discussion}

Weed density and growth were dependent on plant spacing, showing a decline at narrow spacing until intra-row spacing was $20 \mathrm{~cm}$ (Tables 1 and 2 ). As a planophile, the orange-fleshed sweet potato at the narrow intra-row spacing of $20 \mathrm{~cm}$ had a high LAI of 5.0. at 12WAP, which gave good ground cover and suppressed weeds. The $40 \mathrm{~cm}$ wider spacing had lower LAI of 1.7, but higher weed population (Table 3 ). This result 
Table 4. Effect of plant spacing and variety on biomass ( $t / h a)$ of orange fleshed sweet potato at 16WAP in 2013 and 2014

\begin{tabular}{|c|c|c|c|c|}
\hline \multirow[t]{3}{*}{ Variety } & \multicolumn{3}{|c|}{ Plant spacing $(\mathrm{cm})$} & \multirow[b]{3}{*}{ Mean } \\
\hline & \multirow[b]{2}{*}{20} & \multicolumn{2}{|l|}{2013} & \\
\hline & & 30 & 40 & \\
\hline Umuspo 3 & 5.67 & 4.11 & 3.42 & 4.40 \\
\hline Umuspo 1 & 12.00 & 15.00 & 12.42 & 13.14 \\
\hline Ex-Oyunga & 6.50 & 5.78 & 3.75 & 5.34 \\
\hline Ex-Igbariam & 10.42 & 7.89 & 8.08 & 8.80 \\
\hline \multirow[t]{2}{*}{ Mean } & 8.65 & 8.20 & 6.92 & 7.92 \\
\hline & & \multicolumn{2}{|l|}{2014} & \\
\hline Umuspo 3 & 15.20 & 8.40 & 7.00 & 10.20 \\
\hline Umuspo 1 & 45.30 & 34.40 & 26.80 & 35.50 \\
\hline Ex-Oyunga & 13.00 & 8.60 & 6.80 & 9.47 \\
\hline Ex-Igbariam & 32.00 & 20.90 & 15.80 & 22.90 \\
\hline \multirow[t]{2}{*}{ Mean } & 26.38 & 18.08 & 14.10 & 19.52 \\
\hline & & 2013 & 2014 & \\
\hline $\operatorname{LSD}_{(0.05)}$ for spacing (S) Mean & & $=$ & NS & \\
\hline $\operatorname{LSD}_{(0.05)}$ for variety (V) Mean & & $=$ & 5.54 & \\
\hline $\operatorname{LSD}_{(0.05)}$ for S x V Mean & & $=$ & NS & \\
\hline
\end{tabular}

$\mathrm{NS}=$ Not significant at $\mathrm{P}<0.05$

agrees with the findings of O'Donovan (1994) and Njoku et al. (2009) that the competitive effect of weeds was reduced when the seeding rate increased from low density (wider spacing) to a higher density (closer spacing). Evidently, crop canopy closure developed much earlier in plots where the orange fleshed sweetpotato was planted at the closer spacing of $20 \mathrm{~cm}$ resulting in shading that reduced weed density and dry matter.

Plants in the narrow row spacing yielded more than those in the wider row spacings (Table 6). Storage root yield increased as population increased with the highest yield, occurring at the narrow row spacing $(20 \mathrm{~cm})$, which was the highest population of 50,000 plants/ha. The narrow spacing $(20 \mathrm{~cm})$ consistently out-yielded the wider row spacings of 30 and $40 \mathrm{~cm}$ by 52 and $108 \%$, respectively on average. The storage root yield of $23.5 \mathrm{t} / \mathrm{ha}$ was obtained at the narrow row $(20 \mathrm{~cm})$, which also produced the highest shoot biomass of $17.6 \mathrm{t} / \mathrm{ha}$.

Storage root yield correlated negatively $\left(r=-0.566^{* *}\right)$ and significantly with intrarow spacing. The total yields increased at 
Plant spacing and variety on weed and performance of orange-fleshed sweet potato

Table 5. Effect of plant spacing and variety on number of storage roots/plant of orange fleshed sweet potato in 2013 and 2014 at 16WAP in 2013 and 2014

\begin{tabular}{|c|c|c|c|c|}
\hline \multirow[t]{3}{*}{ Variety } & \multicolumn{3}{|c|}{ Plant spacing $(\mathrm{cm})$} & \multirow[b]{3}{*}{ Mear } \\
\hline & \multirow[b]{2}{*}{20} & \multicolumn{2}{|l|}{2013} & \\
\hline & & 30 & 40 & \\
\hline Umuspo 3 & 1.63 & 1.43 & 1.27 & 1.44 \\
\hline Umuspo 1 & 1.97 & 2.07 & 2.26 & 2.10 \\
\hline Ex-Oyunga & 0.55 & 0.84 & 0.47 & 0.62 \\
\hline Ex-Igbariam & 1.36 & 1.16 & 1.38 & 1.30 \\
\hline \multirow[t]{2}{*}{ Mean } & 1.38 & 1.38 & 1.35 & 1.37 \\
\hline & & \multicolumn{2}{|l|}{2014} & \\
\hline Umuspo 3 & 2.30 & 2.20 & 2.20 & 2.23 \\
\hline Umuspo 1 & 2.40 & 2.50 & 2.50 & 2.47 \\
\hline Ex-Oyunga & 1.10 & 1.10 & 1.00 & 1.07 \\
\hline Ex-Igbariam & 2.10 & 2.50 & 2.60 & 2.40 \\
\hline \multirow[t]{2}{*}{ Mean } & \multirow[t]{2}{*}{1.98} & \multirow[t]{2}{*}{2.08} & 2.08 & 2.04 \\
\hline & & & 2013 & 2014 \\
\hline LSD (0.05) for spacing (S) Mean & & $=$ & NS & NS \\
\hline LSD (0.05) for variety (V) Mean & & $=$ & 0.40 & 0.30 \\
\hline LSD (0.05) for S x V Mean & & $=$ & NS & \\
\hline
\end{tabular}

NS $=$ Not significant at $\mathrm{P}<0.05$

the closer spacing probably due to increase in the number of plants per unit area, which contributed to the production of extra yield (Law-Ogbomo and Egharevba, 2009). Similar observations were reported on yams (Okpara et al., 2013; Ikoro et al., 2014). The wider intra-row spacings of 30 and $40 \mathrm{~cm}$ did not produce high number of storage roots that could compensate for the reduced number of plants per unit area, compared to the narrow row of $20 \mathrm{~cm}$. Consequently, planting the orange fleshed sweetpotato at the narrow row $(20 \mathrm{~cm})$ favoured the plants and resulted in greater yield because there was enough space for the plants to express full potential and intercept more solar energy. The increase in the number of plants per unit area contributed more yield per unit area.

For the cultivars, Umuspo 1 produced higher shoot biomass, suppressed weeds more effectively and out-yielded other varieties, indicating better adaptation to Umudike conditions in the humid environment of south eastern Nigeria. Umuspo 1 produced the highest storage 
Table 6. Effect of plant spacing and variety on storage root yield (t/ha) of orange fleshed sweet potato in 2013 and 2014

\begin{tabular}{|c|c|c|c|c|}
\hline \multirow[t]{3}{*}{ Variety } & \multicolumn{3}{|c|}{ Plant spacing $(\mathrm{cm})$} & \multirow[b]{3}{*}{ Mean } \\
\hline & \multicolumn{3}{|c|}{2013} & \\
\hline & 20 & 30 & 40 & \\
\hline Umuspo 3 & 14.56 & 10.39 & 7.96 & 10.97 \\
\hline Umuspo 1 & 18.75 & 13.35 & 15.88 & 15.99 \\
\hline Ex-Oyunga & 3.05 & 1.98 & 1.66 & 2.23 \\
\hline Ex-Igbariam & 4.48 & 4.40 & 4.27 & 4.38 \\
\hline Mean & $\begin{array}{l}10.21 \\
2014\end{array}$ & 7.53 & 7.44 & 8.39 \\
\hline Umuspo 3 & 46.30 & 24.50 & 16.50 & 29.10 \\
\hline Umuspo 1 & 56.30 & 36.80 & 22.00 & 38.37 \\
\hline Ex-Oyunga & 15.20 & 9.60 & 6.60 & 10.47 \\
\hline Ex-Igbariam & 28.60 & 23.20 & 15.10 & 22.30 \\
\hline Mean & 36.60 & 23.53 & 15.05 & 25.06 \\
\hline & & & 2013 & 2014 \\
\hline LSD (0.05) for spacing (S) Mean & & $=$ & 1.42 & 4.20 \\
\hline LSD (0.05) for variety $(V)$ Mean & & $=$ & 5.40 & 4.50 \\
\hline LSD (0.05) for S x V Mean & & $=$ & NS & 7.50 \\
\hline
\end{tabular}

NS $=$ Not significant at $\mathrm{P}<0.05$

Table 7. Correlation between spacing and yield of orange-fleshed sweetpotato in 2013 and 2014

\begin{tabular}{llcc}
\hline & \multicolumn{2}{c}{ Correlation with } \\
\cline { 2 - 3 } & \multicolumn{2}{c}{ Root yield (t/ha) } & \multicolumn{2}{c}{ Shoot biomass (t/ha) } \\
\hline Spacing & $-0.149 \mathrm{~ns}$ & & $-0.123 \mathrm{~ns}$ \\
Spacing & & $\mathbf{2 0 1 4}$ & $-0.397 *$ \\
\hline
\end{tabular}

* Significant at $5 \%$ probability level, $* *$ significant at $1 \%$ probability level, NS $=$ Not significant at $\mathrm{P}<0.05$ 
root yield (27.2t/ha), followed by Umuspo 3 ( 20.0t/ha); while Ex-Oyunga had the lowest yield (6.4t/ha). The yield differences were probably due to the tendency to have a strong ability to accommodate more assimilates in the storage root by the high yielders. Interactions were significant for storage root yield in 2014, with Umuspo 1 producing the highest yield at the narrow row $(20 \mathrm{~cm})$; followed closely by Umuspo 3. The poor performance of Ex-Oyunga could be attributed to its poor adaptation to the humid environment of south eastern Nigeria, since the cultivar was introduced from CIP, Nairobi Kenya.

The official recommendation in Nigeria for spacing in sweetpotato at the time of initiation of this experiment was $1 \mathrm{~m}$ x 30 $\mathrm{cm}$, with 33,300 plants/ha (Egeonu and Akoroda, 2009). However, the results of the present study showed that intra-row spacing could be further reduced to $20 \mathrm{~cm}$ to give higher leaf area index and biomass, suppress weeds and produce higher storage root yield in orange-fleshed sweetpotato. Increasing spacing from 20 to $40 \mathrm{~cm}$ reduced yield from 23.5 to 11.3 t/ha on average, giving $52 \%$ yield reduction at $40 \mathrm{~cm}$ intra-row spacing. The closer intra-row spacing of $20 \mathrm{~cm}$ was therefore sufficient to enhance yield and is recommended. Umuspo 1 was more efficient in suppressing weeds and produced the highest storage root yield, followed by Umuspo 3. Yields were generally higher in 2014, in which planting was done earlier in May and viral infection was low due to the use of clean or healthy vines.

\section{References}

Akintoye, H.A., Kintomo, A.A. and Adekunle, A.A. 2009. Yield and fruit quality of water melon in response to plant population. International Journal of Vegetable Science 15:369380.

Carmer, S.G. and Swanson, M.R. 1971. Detection of differences between means. A monte Carlo study of five pair wise multiple comparison procedures. Agronomy Journal 63: 940-945.

Food and Agricultural Organization (FAO), 2011. Faostat annual report Fao(1) $\mathrm{Http} / /$ es.wikipedia the encyclopaedia Egeonu, I.N. and Akoroda, M.O. 2009. Missing stands in sweet potato field trials. In: Sweet potato in Nigeria (eds. Malachy Akoroda and Ijeoma Egeonu). Proceedings of the first National Sweet potato Conference held during 16-18 September, 2008 at Ibadan, Nigeria.

GenStat, 2007. GenStat Discovery Edition 3. Lawes Agricultural Trust (Rothamsted Experimental Station), UK.

Hahn, S.K. and Hozyo, Y. 1998. Sweet potato reprint series, International Institute of Tropical Agriculture (IITA), Ibadan and Agricultural Research Centre, Yatabe Tsukebe 305 Japan.

Ikoro, A.I., Okpara, D.A. and Ikeogu, J. 2014. Effects of nodes per vine and planting density on leaves and yield of water yam in south eastern Nigeria. Journal of Applied Agricultural Research 6: 219 -226.

Kelm, m., Bruck, H., Hermann, M. and Sattelmacher, B. 2001. Plant productivity and water use efficiency of sweet potato (Ipomea batatas) as affected by nitrogen supply. CIP Program Report 1999-2000. http.// www.cipotato.org/market/pgmrprts/ pr99-00/34waternpdf. 
Law-Ogbomo, K. and Egharevba, E. in a humid agro ecological zone. 2009. Effect of planting density and Nigerian Agricultural Journal NPK fertilizer application on yield and yield components of tomato in forest location. World Journal of Agricultural Science 5: 152-158.

National Root Crops Research Institute (NRCRI), 2005. National Root Crops Research Institute, Umudike Annual Report.

Nedunchezhiyan, M., Byju, G. and Jata, S.K. 2012. Sweet potato Agronomy, Regional Centre of Central Tuber Crops Research Institute, Bhubaneswar - 751019, India. 40:115-124.

O'Donovan, J.T. 1994. Conola (Brassica rapa) plant density influence Tartary Buck wheat (Fagoprum tataricum) interference, biomass and seed yield. Weed Science 42:385-389.

Okpara, D.A., Ikoro, A.I. and Ojikpong, T.O 2013. Water yam microsett responses to plant density and mulching in southeastern Nigeria. African Journal of Root and Tuber Crops 10:55-60.

Ray, R.C. and Ravi, V. 2005. Post harvest spoilage of sweet potato and its control measures. Critical Review of Food Science and Nutrition 35:623-644. and Ekeleme, F. 2009. Effect of propagule size and intra-row spacing on the growth and yield of sweet potato 